http://www.pakjas.com.pk

\title{
IMPACT EVALUATION OF A KAREZ IRRIGATION SCHEME IN BALOCHISTAN-PAKISTAN: ISSUES AND OPTIONS
}

\author{
M. Ashraf ${ }^{1, *}$, A. Majeed² and Mazhar Saeed ${ }^{3}$ \\ ${ }^{1}$ Pakistan Council of Research in Water Resources, Khyaban-e-Johar Road H-8/1, Islamabad; Pakistan; \\ ${ }^{2}$ International Union for Conservation of Nature (IUCN), Islamabad, Pakistan; ${ }^{3}$ Higher Education Commission \\ (HEC), Islamabad, Pakistan \\ "Corresponding author's e-mail: muhammad_ashraf63@yahoo.com
}

\begin{abstract}
In Balochistan, karezes are one of the oldest irrigation systems. However, these are vanishing due to a number of technical, socio-economic reasons. A study was undertaken on a representative irrigation scheme of Dilsora to document its impact on the socio-economic conditions of the local community, present issues and to propose remedial measures. A questionnaire survey was conducted to collect primary information from the farmers regarding impact of the scheme, constraints faced by the farmers and suggestions for its improvement. Flow was measured with a Pigmy type digital current meter at the head and tail reaches to determine the discharge and conveyance losses in the karez channel. The analysis of the survey revealed that the implementation of the scheme had a positive impact on the socio-economic conditions of the local community by (i) increasing the volume of water, irrigated area, crop yields and farm income, (ii) reducing the maintenance (both in terms of physical and financial liabilities), dispute over water, drudgery on women, and (iii) reducing the soil erosion. The main issues identified are (i) deferred repair and maintenance of the irrigation system, (ii) deterioration of water quality during conveyance, (iii) non-functional water user association, (iv) lack of watershed management activities, and (vi) irrational installation of tubewells in the vicinity of the karez. The karez system is unique in the world and provides water free of cost to the local community round the clock and throughout the year. It must, therefore, be sustained by regularly cleaning and protecting it from floods. The scheme is also a source of drinking water for the local community. Therefore, its maintenance is not only important for irrigation point of view but also for providing clean drinking water to the community, but carrying out watershed management and artificial recharge activities in the karez recharging zones, and controlling the irrational installation of tubewells, particularly within the karez recharging zones.
\end{abstract}

Keywords: Socio-economic, groundwater, tubewells, watershed management, irrigation water.

\section{INTRODUCTION}

During the past several decades, increasing water demand for irrigation has been met by developing new sources of water. However, the technical, economic and environmental costs associated with the continued development of new sources make this approach limited to fulfill the entire demand. On the other hand, in many countries the allocation of water for irrigation is viewed as a low priority. As a result, more recently, irrigation has received a reduced share of the total supply due to increased demand from higher valued uses such as industrial, domestic and recreational. For example, in developing countries the share of water for agricultural uses was $90 \%$ in 1995 and is expected to reduce to $70 \%$ in 2020 (Pinstrup-Andersen et al., 1997).

In Pakistan, water shortfall of $11 \%$ in 2004 will increase to $31 \%$ by 2025 (GoP, 2001). Total water availability at the farmgate (both surface and groundwater) is about $163 \times 10^{9}$ $\mathrm{m}^{3}$. Presently, about $7 \%$ of the available water is used for domestic and industrial purposes mostly being met from groundwater. About $93 \%$ of the available water is used for agriculture (GoP, 2001). Out of 80 million hectare (Mha) total geographical area of Pakistan, 29.6 Mha is culturable and 13.6 Mha is canal irrigated. About 9.7 Mha of more land could be irrigated if water is available. Due to increased population, urbanization and industrialization, per capita water availability has decreased from $5600 \mathrm{~m}^{3}$ to about $1000 \mathrm{~m}^{3}$ over the last fifty years. Water storage per capita and water productivity is also very low.

Balochistan, the largest province of Pakistan, lies in the arid climatic region, making irrigation essential for crop growth. The spatial and temporal variability of rainfall is very highover $400 \mathrm{~mm}$ in the north to as low as $50 \mathrm{~mm}$ in the south (Ashraf and Majeed, 2006). Soils are mostly thin calcareous and low in organic matter. However, these soils respond well to organic and inorganic fertilizers. In the absence of sustainable and perennial surface water supplies, there has been increasing dependence on groundwater to meet the growing agriculture and domestic requirements of the province. Due to irrational pumping, the water table is depleting at more than $3 \mathrm{~m}$ per year in many river basins of Balochistan. The Pishin-Lora Basin has almost exhausted. 
The Nasirabad Division (Nasirabad, Bolan, and Jaffarabad districts) is the only division of the province, where an organized canal irrigation system is practiced (only $5 \%$ of the geographical area of the province). The remaining $95 \%$ depends upon minor perennial and flood irrigation system to meet the requirements of all the sectors (domestic, agriculture, industry, mining and ecosystem).

The different types of irrigation schemes include (i) sailaba (flood) irrigation under which run-off waters from perennial or non-perennial streams is diverted and used on farms and agriculture fields; (ii) khushkaba (rainwater harvesting) irrigation whereby crops are solely dependent on rain. Under this system, the sheet flow from mountain sides during rainstorms is collected and conserved in the piedmont plains by constructing low dykes across flow paths; (iii) lift irrigation in which water is pumped from underlying aquifers. Tubewells and dug wells are classified under this system of irrigation; and (iv) spring and karez irrigation systems in which groundwater is tapped and conveyed by gravity in open channels or underground tunnels to command areas. A karez picks up water from a mother well, either an underground spring in the piedmont zone or a subsurface flow on the bank of a temporary river and conveys water over a length of 500$3000 \mathrm{~m}$, before it daylights close to the agricultural command area (Fig. 1). These systems were typically constructed on a collective basis and the cost of establishment and maintenance were high. It is also known as karez in China, Qanat in Iran and Foggara in Tunisia. These are masterpieces of engineering technology. It is a unique system in the world and provides water through gravity, round the clock and throughout the year. The first two types of water application/conservation for agriculture practices, however, use only a small fraction of the total water resources, though the area under such techniques is quite large (53\% of the total cultivated area).

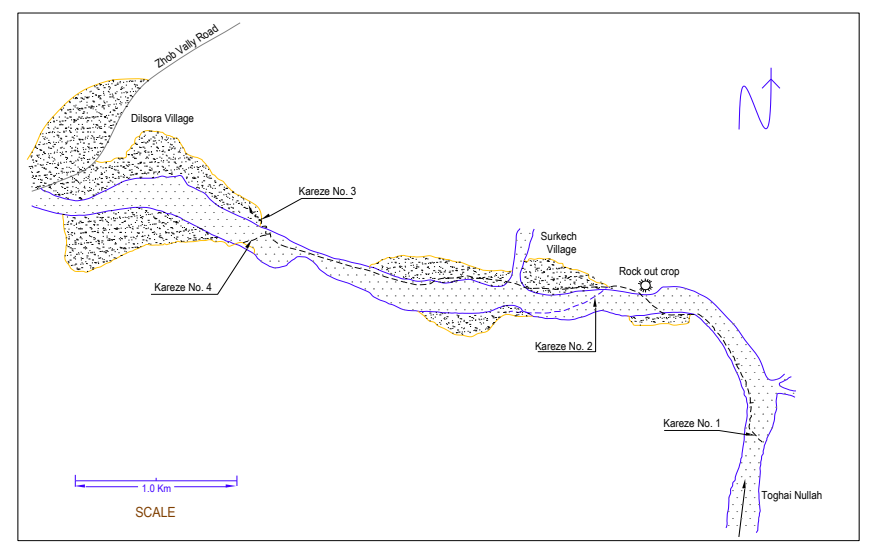

Figure 1. Schematic diagram of the Dilsora irrigation scheme-Balochistan, Pakistan.

The provincial Irrigation and Power Department (IPD) has been responsible for developing surface water resources by constructing small and medium capacity storage dams and executing a number of minor/small perennial and flood irrigation schemes in various parts of the province. Most of these schemes have been completed with donor's assistance. (BMIADP, 1987) The department has completed about 85 flood irrigation and over 250 perennial irrigation schemes covering command area of about 80,000 ha, representing

Table 1. Salient features of the Dilsora irrigation scheme.

\begin{tabular}{ll}
\hline Source of water & Four small karezes in the river bed \\
Designed flow (lps) & 71 \\
Irrigation cycle (days) & 17 \\
Number of beneficiaries & 1400 \\
Number of shareholders & 200 \\
Cropping pattern & \\
Kharif (April-September) & Tomatoes, onion, potatoes, maize, sorghum, pulses \\
Rabi (October-March) & Wheat, barley, vegetables, fodder wheat, peas, cumin \\
Perennial & Apples, apricot, pomegranates, plums, grapes, alfalfa \\
Command area before improvement (ha) & 51 \\
Command area after improvement (ha) & 68 \\
Year of completion & 1990 \\
Registration of WUA and handing over & 1991 \\
the scheme & \\
Component of main work & Conduit (631 m), siphons (5 No.), culverts (5 No.), channel lining (4760 m), \\
& washing structures (5 No.), covered channel lining (134 m), Outlet (700 No.), \\
& drop structures (8 No.), inspection chambers (7 No.), sump structures (5 No.), \\
& super passages (5 No.), cross drainage structures (2 No), gabion protection \\
& wall (3358 m) and gabion spur (529 m) \\
\hline
\end{tabular}

\footnotetext{
$1 \mathrm{US} \$=$ Rs. 60
} 
around $8 \%$ of the total irrigated area. The department has also constructed over 110 delay action dams, over 100 flood protection projects, besides rehabilitating over 77 irrigation schemes. The number of small irrigation schemes, undertaken so far, is about 300 . The three main functions in the management of irrigation scheme are (i) the equal distribution of water; (ii) the management of silt and scour process in the flood channels, and (iii) the maintenance and rehabilitation of the main channel and the diversion structures. However, the sustainability of these schemes has been questionable.

The main function of any irrigation scheme is to provide irrigation water supplies. The yardstick for the evaluation of the irrigation management must be whether it fulfill its function, i.e. the delivery of water where and when it is required, reliably and in the right quantities (Abernethy, 1986). Irrigation performance is based on different types of activities such as planning, design, construction, operation of facilities, maintenance and application of water to the land (Small \& Svendsen, 1990) or agricultural production, irrigation, land settlement, maintenance, construction, water users' organization, etc. (Nijiman, 1992).

However, there are no scientific data to support some divergent views among local stakeholders in Balochistan on the performance of these schemes. This study was undertaken on a representative small irrigation scheme with the objectives to (i) study whether the selected karez-irrigation scheme has met its objectives for which it was designed; (ii) identify the issues and constraints affecting the performance of the scheme; and (iii) draw lessons and make recommendations to improve performance of the scheme.

\section{METHODOLOGY}

Site location: A minor-irrigation scheme named Dilsora, located in the Pishin district at a distance of about $75 \mathrm{~km}$ northeast of Quetta and $40 \mathrm{~km}$, south-west of Muslimbagh was selected for the study. It falls within the Pishin-Lora Basin, one of the most depleted basins in the province. The irrigation system comprised four karezes in the Toghai nullah (stream) with a $5183 \mathrm{~m}$ long channel distribution system, which conveyed the flow from the four karezes to a series of parcels of land on the left and right of the nullah. Much of the channel system runs in the river bed and is susceptible to flood damage. It was anticipated that implementation of the scheme would enable farmers to expand the existing command area from about 17 ha to over 80 ha. About 200 farm families have water rights to the karez system and were therefore, benefiting from the scheme.

The aims of the project were to increase the quantity and reliability of the irrigation supplies to the villages in the command area by lining the conveyance channels, and constructing river crossings and command area development works, by the construction of flood protection works to the karezes and channels, and by removing channels from the river bed (Table 1). It was anticipated that lining of the channels and other works proposed would result in elimination of seepage losses from the channels and saving of about 14 lps water, that was being lost from the system as seepage losses (BMIADP, 1987).

Climate: The climate of the area is cold in winter, often with an intensely chilling wind, but hot and dusty in summer. Maximum and minimum average temperatures recorded in Muslimbagh, the nearest climate station at $40 \mathrm{~km}$ distance are $27.5^{\circ} \mathrm{C}$ in July and $3.7^{\circ} \mathrm{C}$ in January, respectively. The average annual rainfall recorded at Pishin rainfall station, 32 $\mathrm{km}$ to the west, is $231 \mathrm{~mm}$ and $243 \mathrm{~mm}$ at Muslimbagh. Most of the precipitation falls in the winter and early spring.

Topography and soils: The command area comprises a number of small irrigated patches on either side of the Toghai nullah. Towards the tail end of the command area, the land opens out on both sides of the nullah to a large area of uncultivated land suitable for irrigation. Most of the irrigated land is relatively flat with a few minor undulations. The soils are alluvial in origin, and calcareous in nature, comprising light to silty loams. The soil profile is generally deep, offering no constraints to cultivation.

Irrigation system: Before the implementation of the project, the water was being abstracted from the sub-surface flow in the Toghai nullah by means of four karezes. The flows from these karezes were combined to serve various irrigated tracts on both banks of the nullah. A schematic diagram depicting the water abstraction arrangements is given in Figure 2. The Karez 1 daylights at a point on the left side, some $5 \mathrm{~km}$ up the Toghai nullah from the main road. This karez was dug into the nullah bed, a distance of $300 \mathrm{~m}$ upstream, and was believed to cross the nullh obliquely and to be quite shallow. This karez was the largest and the most reliable. The outlet of this karez marks the upper boundary of the land owned by the benefiting villages.

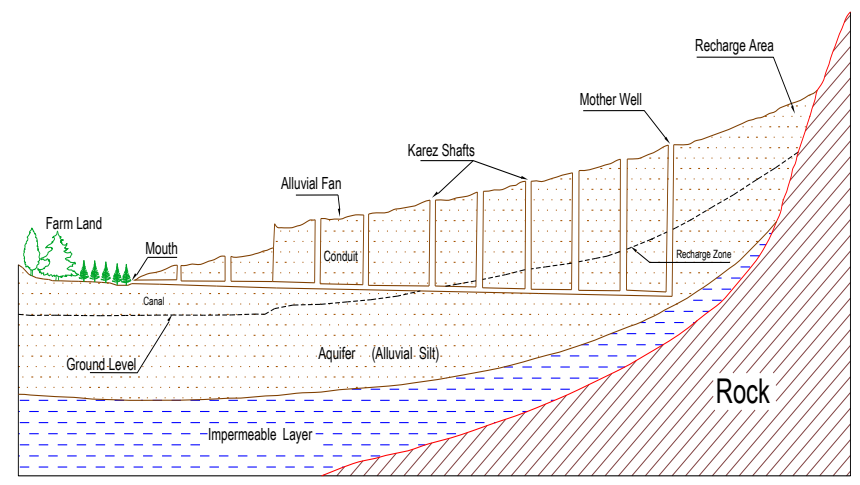

Figure 2. A schematic diagram of a karez.

The Karez 2 is small, located $1 \mathrm{~km}$ downstream of the first, daylights on the right side of the nullah and originates from an obliquely running tunnel in the bed of the nullah. The flow from it joins the main channel of the Karez 1 close by. This karez was reported to be less than $5 \mathrm{~m}$ deep. The Karez 3 is 
also small and originates from the nullah bed and daylights on the right side of the nullah at about $1 \mathrm{~km}$ from the road crossing the nullah, joins the main channel serving the village of Dilsora. The mother well to this karez was reported to be about $18 \mathrm{~m}$ deep. The Karez 4 also originates from the nullah bed, day lights on the left side and serves exclusively irrigated land on the left or western side of the Toghai nullah. The mother well to this karez was about $15 \mathrm{~m}$ deep (BMIADP, 1987).

Discharge: The flow measured on $31^{\text {st }}$ August, 1987 (during the period of peak crop water requirements), from the four karezes was about $51 \mathrm{lps}$ (Table 2). It was estimated that about 14 lps (28\%) of this was being lost through seepage from the conveyance system (BMIADP, 1987). The original discharge of Karez 1 was almost 4 times more than the other 3 karezes and was even more than the total flows of the karezes 2, 3 and 4. The Electrical Conductivity (EC), Sodium Adsorption Ration (SAR) and Residual Sodium Carbonate (RSC) of the water as measured on $31^{\text {st }}$ August 1987 were $1.14 \mathrm{dS} \mathrm{m}^{-1}, 2.0$ and 0 , respectively. The discharge was also measured on $24^{\text {th }}$ January, 2007 with a Pigmy type digital current meter at the head and tail reaches to determine the present discharge and conveyance losses in the channels. The water samples were also collected from head, middle and tail reaches of the scheme on $5^{\text {th }}$ March, 2007 and analyzed for its quality.

Table 2. Discharge of the karezes as measured on $31^{\text {st }}$ August, 1987.

\begin{tabular}{lc}
\hline Karez No. & Discharge (lps) \\
\hline 1 & 28 \\
2 & 7 \\
3 & 7 \\
4 & 9 \\
Total & 51 \\
\hline
\end{tabular}

Source: BMIADP (1987).

Water rights: There are 200 water rights holders in the command area served by the scheme. The water distribution system is complex. The village of Surkech receives water from the upper two karezes for a period of 2 days out of 12 in summer. The water is taken across the river to serve upper areas on the left bank for one day. For the remaining 9 out of 12 days, the water from the upper two karezes is taken downstream, where it joins with the water from the third karez. This combined flow is shared as follows:

- The villages of Dilsora, Lasht and Gus Baloch receive the full combined flow of the three upper karezes for 5 days.

- The combined water from the three upper karezes is passed across the katcha (unlined) nullah crossing to the left bank for the remaining 4 days. This water combines with that coming from Karez 4, which is normally available to left bank users on a continuous basis.

A 43 days and nights rotation prevails in winter, which is reduced in summer to 20 days and nights. The largest share is
3 days and nights and the smallest share is only 3 hours. In addition, water is bought and sold. The water was being sold at a rate of Rs 100 per hour (1 US\$ = Rs 60) diversion of the full supply in 1987. A Water Users Association (WUA) is responsible for the management of the irrigation system, as well as maintenance and all the repair work required.

This site was selected for monitoring with the criteria that it: (i) has maximum of four karezes at one location (ii) has all the infrastructure i.e. conduit, culverts, siphons, channels, naccas, washing structures, flood protection; (iii) serves a large community and large command area; and (iv) has relatively easy access.

Questionnaire survey: A specially designed questionnaire was used to collect primary information from the farmers regarding the impact of the scheme, constraints faced by the farmers, suggestions for improvement etc. The questionnaire was pre-tested in the field. There are 200 water shareholders in this scheme. Twenty five percent of these shareholders were selected for interview. About one third of these were selected each from head, middle and tail reaches of the scheme. These farmers were selected randomly. Statistical Package for Social Scientists (SPSS) was used to analyze the data collected. Secondary data were collected from the relevant department/agency. Discussions were also made with the related government agencies such as Agri. Extension and/Irrigation and Power Department and the local notables such as head of the WUA. The farmers perceptions regarding these issues were assigned different weights with reference to priority to look deep insight about the gravity of these issues. The weights were further aggregated to yield their percent share towards entire problems. The scheme was inspected physically and any leakage, overflow or damage was noted.

\section{RESULTS AND DISCUSSION}

As discussed earlier, the main objective of the scheme was to increase the quantity and reliability of the irrigation water supplies to the villages in the command area. Therefore, the key indicators were to see whether there were: increase in water supply, irrigated area, farm income, decrease in maintenance required, reduction in dispute over water (equity in water distribution), change in cropping pattern, decrease in labour for operation and maintenance, and increase in crop yield. These indicators are discussed below:

Increased in water supply: According to farmers, before 1998 drought, the scheme was in a very good condition, the WUA was operational and was serving the purpose. The flows of the karezes were enough and the farmers were taking keen interest in the operation and maintenance of the irrigation system. With the implementation of the scheme, the water supply increased from less than 20 to $200 \%$ (Table 3). The farmers at the head and middle reaches reported more increase in water supply as compared to the tail reach. Since the farmers at the head and middle reaches are closer to the 
source therefore, they were the direct beneficiaries of the scheme. The losses increased with increase in the distance from daylight point. Therefore, farmers at the tail reach received less increased supply of water as compared to the farmers at the head and middle reaches.

Increased irrigated areas: The increase in water supply resulted in increased irrigated area. The increase ranges from less than 30 to $200 \%$ (Table 3). However, this increase was more pronounced at the upstream area, most probably due to provision of flood protection works and diversion structures such as naccas (outlets).

Increased farm income: The improvement in the irrigation scheme increased income of the farmers by enabling them more efficient use of water, improving yield, quality, and reducing labour costs. Due to increased and assured water supply and increased area under cultivation, the incomes of the farmers increased from 15 to $60 \%$ (Table 4). However, this increase was not proportional with increase in water supply and the irrigated area. This might be due to increased cost of non-water inputs over the years and the effect of prolong drought that resulted in drying of some of the orchards and reducing production of the others.
Reduction in disputes over water: Equity in water distribution is very important factor for management of water resources. The water wastage during conveyance, due to poor maintenance of water channels, is also a major cause of inequity in distribution and results in frustration, lack of interest in farming and maintenance of watercourses, distrust among water users and disputes over water rights among the users. Poor irrigation management also results in important socio-economic and environmental problems (Pereiera, 1996). Due to improvement of irrigation system; however, there is hardly any dispute over water (Table 5). This is the most positive social impact of the project that helped overcome farmer's disputes over water. The equitable distribution of water is also necessary for maximizing productivity. At the head of the system, the farmers generally apply more water than needed for potential yield and excess water does not improve the productivity but reduces it. If instead the excess water is diverted to another part of the scheme receiving less water, then the production would have been increased.

Change in irrigation methods: The assumption of inadequate water supply is not valid for the area since farmers still

Table 3. Farmers perceptions about increase in volume of water and irrigated area (No.).

\begin{tabular}{lccc}
\hline Increased volume of water $(\%)$ & Surkech (head) & Lashta (middle) & Dilsora (tail) \\
\hline$\leq 20$ & - & - & 12 \\
50 & 3 & 2 & 4 \\
100 & - & 5 & - \\
200 & 5 & & - \\
Increase in irrigated area (\%) & & 1 & - \\
$\leq 30$ & - & - & - \\
50 & 3 & 3 & 16 \\
100 & - & 6 & - \\
200 & 9 & & \\
\hline
\end{tabular}

Table 4. Percentage increase in farm income (farmers reporting in No).

\begin{tabular}{lccc}
\hline Increase in farm income $(\%)$ & Surkech (head) & Lashta (middle) & Dilsora (tail) \\
\hline $15-30$ & 4 & 4 & 13 \\
$30-60$ & 2 & 5 & 1 \\
\hline
\end{tabular}

Table 5. Reduction in dispute, change in irrigation methodsand increase in crop yield.

\begin{tabular}{|c|c|c|c|c|c|c|}
\hline Indicator & \multicolumn{2}{|c|}{ Surkech (head) } & \multicolumn{2}{|c|}{ Lashta (middle) } & \multicolumn{2}{|c|}{ Dilsora (tail) } \\
\hline Response & Yes & No & Yes & No & Yes & No \\
\hline Reduction in dispute over water & 15 & - & 14 & 1 & 15 & 1 \\
\hline Changes in irrigation method & 3 & 10 & 2 & 14 & 3 & 13 \\
\hline Increase in crop yield & 4 & 3 & 4 & 5 & 12 & 1 \\
\hline
\end{tabular}

Table 6. Source of irrigation water and irrigation methods (No.).

\begin{tabular}{lccccc}
\hline Village & \multicolumn{2}{c}{ Source of water } & \multicolumn{2}{c}{ Irrigation methods } \\
\cline { 2 - 6 } & Karez & Both & Basin & Furrow & Border \\
\hline Surkech (head) & 13 & 3 & 9 & 1 & 4 \\
Lashta (middle) & 15 & 2 & 1 & 2 & - \\
Dilsora (tail) & 16 & - & 14 & - & - \\
\hline
\end{tabular}


typically apply water according to traditional practices and the efficient use of water is accidental (Tables 5 \& 6). Almost all the farmers are using conventional flood basins for irrigating the orchards. The more efficient pressurized irrigation systems have not been installed by any farmer. The reasons are cheaper availability of water, higher capital cost of the pressurized systems, and farmers' lack of knowledge about these systems. Some farmers have now started using ditch irrigation. These ditches however, are not properly designed and result in huge losses of water.

Change in cropping pattern: The cropping system in Dilsora is primarily based on high-value orchards. The predominant crops are apples (Pyrus malus), plums (Prunus domestica), and apricots (Prunus armeniaca), with smaller areas of grapes (Vitis vinifera), almonds (Prunus amygdalus), and pomegranates (Punica granatum). Intercropping of younger orchards with alfalfa (Medicago sativa) is common. Due to relatively good return from the orchards and relatively less maintenance requirements, the farmers prefer to grow orchards. The vegetables are high-valued crops but are labour and input (water and non-water) intensive. Therefore, these are seldom grown for commercial purposes. However, vegetables are grown on small scale for domestic uses. Therefore, there is no change in cropping pattern even after the improvement of the scheme.

Increase in crop yields: The increased and assured water supply also encouraged the farmers to increase their cropping intensity resulting in increased crop yields (Table 5). Over all $40 \%$ farmers reported increase in crop yield, whereas $18 \%$ reported no increase in yield.

Reduced labour for maintenance of the system: One of the major social and economic benefits of the scheme is reduction in the labour required to maintain the system. Farmers reported 20 to $80 \%$ reduction in labour after implementation of the scheme (Table 7). Overall $28 \%$ farmers reported $80 \%$ reduction in maintenance required and $32 \%$ farmers reported $75 \%$ reduction in labour requirement for irrigation and maintenance.

Environmental impacts: Due to flood protection works, soil erosion was reduced encouraging the farmers to cultivate their lands, which were at the risk of water erosion. Moreover, due to increased vegetation, the soils were less vulnerable to wind and water erosion. However, the farmers were unable to comment on this aspect.

Main issues and constraints:

System deterioration: The Karezes 1, 3 and 4 are operational whereas Karez 2 has been severely damaged and almost has lost its visibility due to flood and sedimentation. In Karez 1, the siphon has been chocked and the farmers have diverted water through earthen watercourse. The flood in the Toghai nullah caused a drastic damage to the irrigation system. The floods have also caused erosion to the adjacent fields. Therefore, check structures and flood protection walls are required to keep the system operational.

The main channel has been silted up due to sedimentation. There is need to construct conduit in this area to avoid siltation and to convey water to the downstream areas. Due to siltation, the channel has changed its path at several places and is being conveyed through a very poorly maintained watercourse, rather a stream. This shows lack of farmers' interest in the maintenance of the system. Moreover, it also reveals that the farmers have given a very low value to water and consider it as a usual commodity. The diversion structures i.e. naccas are also in very bad condition. Due to flood and sedimentation, all the sumps have been chocked. However, some components of the system such as conduit and water channel at certain places are still in very good condition, even after laps of more than 16 years.

Water lost through deteriorated system: The discharge of the scheme was 51 lps on $31^{\text {st }}$ August, 1987 (BMIADP, 1987). However, the combined discharge of the scheme as measured on $24^{\text {th }}$ January 2007 was 24 lps at the head of the scheme (within $100 \mathrm{~m}$ when karezes daylight) which was $47 \%$ less than the discharge measured in 1987. The reduction in discharge was mainly due to recent drought and non-cleaning of the karezes for the last more than 7 years. The discharge further reduced to $18 \mathrm{lps}$ at the tail reach, measured at $40 \mathrm{RD}$ (reduced distance and $1 \mathrm{RD}=305 \mathrm{~m}$ ). Therefore, $25 \%$ of water is further lost during conveyance due to seepage and evaporation. If the system deterioration continues, it will further reduce the water availability, resulting in severe socioeconomic consequences such as dispute over water, drying of orchards, migration of people etc. The poor community will be the most affected.

Table 7. Percentage reduction in maintenance and labour required (farmers reporting in No).

\begin{tabular}{rccc}
\hline Reduction in maintenance (\%) & Surkech (head) & Lashta (middle) & Dilsora (tail) \\
\hline 20 & 1 & - & 2 \\
11 & 6 & 13 \\
80 & 9 & - & \\
Reduction in labour $(\%)$ & 1 & & \\
25 & & 2 & 6 \\
50 & - & 3 & 8 \\
\hline
\end{tabular}


Water quality deterioration: Due to improper management of the scheme, the water quality also deteriorates during transportation. Table 8 shows that the aesthetic and bacteriological water quality of the scheme close to the source ( $0.5 \mathrm{~km}$ from the daylight point) was very good with slightly higher turbidity. However, during the way, it gets polluted and becomes very poor towards the tail end after passing through the urban area. Similarly, the chemical quality of the water at the head is relatively better except hardness and fluoride (Table 9).

The hardness, nitrate and fluoride are common in the drinking water of Balochistan. Kahlown et al. (2006) found the highest concentration of fluoride in Quetta and nitrate in Ziarat. The hard water precipitates on boiling or when reacts with soap. Such water can cause cardiovascular disease and nuisance. The minor concentration of fluoride in drinking water is beneficial. However, concentration greater than $1.5 \mathrm{mg} / \mathrm{l}$ causes dental fluorosis and in extreme cases skeleton fluorosis and cancer. Nitrate- $\mathrm{N}$ also increases at the middle and decreases towards the tail end and is higher than the WHO guidelines values (Table 9). The main causes of pollution are: its way through stream bed, washing clothes, animal drinking and filth in and around the channel. Excessive nitrate may result in Methaemoglobinaemia and death, and the pregnant women are at greater risk than the general adult population. However, there is no change in EC over the last 20 years. There was almost similar trend in sodium adsorption ratio (SAR), and the residual sodium carbonate (RSC) was zero in all the samples. Therefore, the water quality is good for irrigation purposes. As the scheme is also an important source of drinking water for the local community, its maintenance is also important for providing clean drinking to the local community.

Lack of watershed management activities: Lack of watershed management is one of the major cause of the reduced recharge to the groundwater and siltation of the irrigation schemes. It also results in flash floods which are constant threat to the life and infrastructures of public and local community.

Installation of shallow tubewells: There are about 20 wells along the karezes. The water table in these wells is within 6$9 \mathrm{~m}$ depths. Farmers have installed submersible pumps/turbines of $24 \mathrm{hp}$ with $6-10 \mathrm{~cm}$ delivery pipes to pump water from these wells. According to the farmers, these tubewells are the main cause of reduced water flow in the karezes. The shallow water table indicates that there is a recharge source nearby. It might be the water of the abandoned karez or recharge from the stream bed. Strategies should be developed to harness this shallow water and to put it in the main system for the benefit of all the community.

No use of water during winter: There is no use of water during winter season from December to March except for domestic and livestock purposes. About 186,624 $\mathrm{m}^{3}$ of water leaves the area without any use (assuming $18 \mathrm{lps}$ for a period of 120 days). With an average discharge of $24 \mathrm{lps}$ of the scheme, about $760 \times 10^{3} \mathrm{~m}^{3}$ is available in a year. The Government of Balochistan (GOB) has constructed about 326 delay action dams (DADs) over the last 20 years. The main purpose of these dams is to recharge the groundwater. The average cost of a DAD is about Rs. 19 million with average storage capacity of about $1.12 \times 10^{6} \mathrm{~m}^{3}$ of water. Therefore, the average cost of water is estimated to be about Rs. $17 / \mathrm{m}^{3}$ of water. With the unit cost of water stored in a DAD, the cost of karez water becomes about Rs. 13 million annually. The karez water is available throughout the year and free of contamination, whereas DAD water is hardly available for few months, subjects to huge evaporation losses (3000-5000 $\mathrm{mm} /$ year), requires a system to convey water to the farm, and may be chemically and biologically contaminated. Delay action dams typically have high initial recharge rates, which fall off dramatically with time. However, it has been noted that the delay action dams could not achieve the desired

Table 8. Aesthetic and Bacteriological water quality of the scheme.

\begin{tabular}{|c|c|c|c|c|c|c|}
\hline Location & Colour & Odour & Taste & Turbidity (NTU) & E-coli & Coliforms \\
\hline WHO Guideline Values & Colourless & Odourless & Unobjectionable & 5.0 & Negative & Negative \\
\hline Daylight point & Colourless & Odourless & Unobjectionable & 5.7 & Negative & Negative \\
\hline Mid point & Muddy & Odour & Muddy & 22.3 & Negative & Negative \\
\hline Near Quetta-Loralai road & Yellow & Odour & Muddy & 18.4 & Positive & Positive \\
\hline
\end{tabular}

Table 9. Chemical water quality of the scheme.

\begin{tabular}{|c|c|c|c|c|c|c|c|}
\hline Location & pH & $\mathrm{EC}(\mathrm{dS} / \mathrm{m})$ & SAR & RSC & Hardness (mg/l) & Fluoride (mg/l) & Nitrate-N (mg/l) \\
\hline WHO Guideline Values & $6.5-8.5$ & NGVS & $N G V S$ & $N G V S$ & 500 & 1.5 & 10 \\
\hline Daylight point & 7.35 & 1.17 & 2.07 & 0 & 570 & 17.47 & 1.41 \\
\hline Mid point & 7.65 & 1.25 & 2.26 & 0 & 620 & 18.84 & 18.32 \\
\hline $\begin{array}{l}\text { Near Quetta-Loralai } \\
\text { road }\end{array}$ & 8.33 & 1.21 & 1.78 & 0 & 570 & 17.62 & 11.92 \\
\hline
\end{tabular}

NGVS: No guidelines value set. 
purpose of recharging the groundwater aquifers mainly due to deposition of silt brought in by runoff and high evaporation rate. Therefore, karez system should be managed properly for its sustainability.

Soil erosion: The lack of flood protection and maintenance work has seriously eroded the fertile lands along the main stream apart from damaging the irrigation infrastructure. This has further lost farmers interest in the maintenance of the system.

Nonfunctional water user association (WUA): There are six main functions of the Farmers Organizations- WUAs, described in the Balochistan Irrigation and Drainage Authority Act, 1997. The first and the most important objective of the WUA is "to operate, manage and improve the irrigation and drainage infrastructure comprising minors, distributaries, and drains together with any structures thereon located within the area relevant to the Farmer Organization concerned". However, Table 10 shows that it is not properly functioning due to number of factors, most important due to low illiteracy rate (Table 11), socio-political character, different sects and tribes, difference in status -poor and rich farmers, -small and large farmers.

Table 10. Farmers views about WUA (No.).

\begin{tabular}{lccccc}
\hline \multirow{2}{*}{ Village } & \multicolumn{2}{c}{ WUA exist } & \multicolumn{3}{c}{ WUA functional } \\
\cline { 2 - 6 } & Yes & No & Yes & No & Do not know \\
\hline Surkech (head) & 8 & 6 & 8 & 3 & 6 \\
Lashta (middle) & 8 & 6 & 5 & - & 12 \\
Dilsora (tail) & 6 & 7 & 6 & 3 & 7 \\
Overall & 22 & 19 & 19 & 6 & 25 \\
\hline
\end{tabular}

Table 11. Education level in the area.

\begin{tabular}{lccc}
\hline $\begin{array}{l}\text { Increase in } \\
\text { irrigated area (\%) }\end{array}$ & $\begin{array}{c}\text { Surkech } \\
\text { (head) }\end{array}$ & $\begin{array}{c}\text { Lashta } \\
\text { (middle) }\end{array}$ & $\begin{array}{c}\text { Dilsora } \\
\text { (tail) }\end{array}$ \\
\hline Illiterate & 75 & 93 & 38 \\
Primary & 6 & - & 63 \\
Matric & 6 & - & - \\
FA & 13 & - & - \\
BA & - & 7 & - \\
MA & - & - & - \\
\hline
\end{tabular}

The studies around the world show that self-governing institutions such as WUAs can manage the system more effectively than government (Lam, 1996; Vermillion, 1997; Kloezen et al., 1997; McKay and Keremane, 2006). However, in Pakistan these are seldom sustainable due the reasons mentioned above. There is need of a sustainable WUA that could maintain their improved system along with more effective use of water through improved water management practices.

Non maintenance of the system: In its simplest form, maintenance can be defined as any activity that slows the deterioration of a facility, whether caused by use or aging (Ostrom et al., 1993). Another technically-oriented definition describes maintenance as planned and auditable procedures to pick up problems before they become critical, and tight financial control to prevent waste (New Civil Engineer, 1996). Traditionally, most views of maintenance have at their core the idea of reducing deterioration. However, the physical inspection and interviews with the farmers shows that this component was almost neglected.

This relative neglect has lost economic benefits and depleted the value of capital assets. The primary function of any maintenance program is to ensure that infrastructure functions at a sufficient level of reliability and control to enable operational objectives or targets to be met. If conveyance infrastructure is allowed to deteriorate below some threshold level so that performance objectives cannot be met, the maintenance program has failed. The deterioration of irrigation systems will almost inevitably affect the most vulnerable users of the system- the tail enders who face greater uncertainty over water volumes and timings, and therefore have generally lower levels of production and income (Murray-Rust et al., 2003).

No cost recovery of irrigation schemes: The GOB does not recover the public investment made on the infrastructure of the irrigation scheme. Since the farmers have to pay nothing for the infrastructure or for the water they use, therefore they do not own it and are least concerned about its maintenance. This is one of the major causes of the system deterioration and low irrigation efficiency. The farmers should be charged based on the water they use and this money may be a part of their revolving fund that could be used for repair and maintenance of the system.

Non involvement of IPD in system maintenance: After the completion of the scheme, it was handed over to WUA in 1991. However, after accomplishment of huge investment, there was no role of IPD to be played in the operation and maintenance of the system. This is an example of "buildneglect-rebuild". This neglect results in shrinking of irrigation service areas, inefficient and inequitable distribution of water, loss of capacity to measure and control water, loss of agricultural productivity, declines in farm income, inability to collect water charges from farmers, and substantial debt burdens on governments which must repay loans for premature and repeating rehabilitation projects (Huppert et al., 2003).

There is general agreement amongst irrigation experts, that deferred maintenance is one of the most important determinants of poor performance of irrigation. There is a relative lack of attention to the maintenance problem by government officials, irrigation agency staff, farmers and international development agencies. Maintenance needs to be perceived as a process where multiple actors have to invest money, time, physical and mental effort, attention and other suitable resources in order to generate the desired result i.e. provision of high quality maintenance services (Huppert et al., 2003). 
Lack of coordination: There is complete lack of coordination among the IPD, Agriculture Department and the farmers- the WUA. The farmers are neither trained about the proper operation, repair and maintenance of the irrigation schemes nor are given any training about high efficiency irrigation system, resulting in overall low irrigation efficiency.

\section{Remedial Measures:}

Rehabilitation of the system: The population of Balochistan is about 6.51 million and is growing at an annual rate of $2.42 \%$. With this growth rate, the population of the province would be around 14 million by 2030 (BCS, 2000). Therefore, it is obvious, that much of the growth in future food production will need to come from improvements in the operation of existing irrigation systems and the resulting increase in water productivity.

The karez irrigation system is the peculiar and the oldest gravity irrigation systems of Balochistan which was built centuries ago. It provides free water supply for both irrigation and domestic uses, round the clock and throughout the year. It is owned and managed by the community and every community member benefits from it in one or the other way. The other sources such as tubewells are owned by individuals, need heavy capital investment, require energy for its operation and can be operated for specific period of time (e.g. when electricity is available). It should therefore, be rehabilitated, particularly cleaning of the karezes, desilting of channels, sumps and repairing of channels and naccas. The assistance may be provided to the farmers for the rehabilitation and maintenance of the system. The poor farmers will be the ultimate beneficiaries of the rehabilitation works whose livelihood entirely depends on farming (agriculture and livestock) for which adequate availability of water is very crucial.

Watershed management: The flows of these karezes are declining with time due to siltation and decrease in recharge. Sustainable groundwater management requires that there should be a balance between recharge and abstraction: This can be achieved through: (i) increasing the groundwater recharge and/or reducing the abstraction rate from the aquifer (Ashraf and Majeed, 2006). Watershed management at the upstream of the scheme is very important to reduce the silt and recharge the aquifer. Construction of check structures, leaky dams, ditches, dikes along with plantation would enhance recharge to the aquifer resulting in sustainable water supply.

Flood protection work: The maximum damage occurred to the scheme due to floods. The flood deteriorated the system by silting up the karezes, tunnels, damaging the infrastructure, silting up conveyance channels, sumps, conduits etc. and erosion of the fertile agricultural lands. Therefore, efforts should be made to protect the entire system from flood by providing flood protection works at appropriate locations.

Control over water wastage: There is no use of water during winter season from December to March, except for domestic and livestock uses. Therefore, huge quantity of water $\left(186,624 \mathrm{~m}^{3}\right)$ is lost without use during this period. Strategies should be developed either to store this precious water under ground or in surface storage for its subsequent use at the time of need.

Proper System for Maintenance: After the implementation of the scheme, there is no formal mechanism for the repair and maintenance of the system, except a WUA which is not functional. The IPD spent about Rs. 11.82 million for the improvement of the system which is over Rs. 1,24,000 per ha of the command area. However, no public investment made on the minor irrigation scheme was recovered from the farmers, resulting in lack of ownership of the scheme. Moreover, there is no involvement of IPD after completion of the project. The WUA may be authorized to collect abiana (water rates), in the form of a revolving fund, for day to day maintenance and the IPD should have a role in the annual repair and maintenance of the entire system with the participation of the WUA. Annual cleaning and maintenance may be done during winter when there is no use of water for irrigation purpose.

The Government of Pakistan and GOB are jointly providing subsidy of around Rs. 7 billion (year 2004-05) to the electric tubewell owners which are about 7000 in the province. This number is based on the actual number of tubewells in operation and assuming that on an average a farmer owns two tubewells. Therefore, the subsidy comes to be Rs. 1 million per farmer per year. The electric tubewell owners represent only $3 \%$ of the total farmers in Balochistan (around 243,000 farms) and therefore, this huge subsidy goes to about 7000 individuals, mostly rich farmers, which are only $3 \%$ of the total farmers and $0.1 \%$ of the total population (around 6.51 million population). The same subsidy may be extended for the sustainability of these conventional sources. The scheme may be considered as a tubewell and subsidy equivalent to one electrically-operated tubewell may be provided by the GOB to the revolving fund of WUA for the repair and maintenance of the system, flood protection works and also for groundwater recharge activities.

Control over installation of tubewells: For sustainable groundwater management, there should be a balance between water abstraction and recharge. The karezes provide gravity flow free of cost throughout the year. Therefore, any intervention that affects their performance should be avoided. The indiscriminate installation of tubewells particularly, in the vicinity of karezes recharging zones, should be banned. Any violation in this regard should be dealt strictly.

Improvement in the efficiency of the system: There are many ways to improve the efficiency of the system: (i) improving hardware of the scheme (developing catchment area, installation of water regulatory and measurement structures, flood protection works, watershed management, development of water storage on upstream area, repairing and enhancing maintenance of existing irrigation systems etc.), (ii) adopting 
water saving methods (pressurized irrigation, improvement in traditional surface irrigation systems such as furrow, alternate furrow, surge irrigation etc.) and (iii) improving the software of the scheme (adoption of appropriate water distribution method, developing optimum allocation plans for land and water resources to different crops in the irrigation scheme, institutional reforms, improving capital related activities and improving crop related management practices etc.). These options are not alternatives but generally applied together. Recently there has been greater interest in 'software' related options that focus on using every drop of available water to its maximum potential (Gorantiwar and Smout, 2006).

Integrated water resources management approach: A single approach however, may not be effective e.g. water saved by watercourse lining may be wasted in field due to undulated fields and improper size of border/basin, and due to over irrigation. An integrated approach would therefore, be an important option to solve the problem of mismanagement of the water resources by adopting an appropriate package of available technologies and agronomic practices. It should also include plan for capacity building of the WUA for repair, maintenance and operation of the irrigation systems.

Conclusions: The implementation of the scheme had a positive impact on the socio-economic conditions of the local community and on the environment by increasing the volume of water, irrigated area, crop yields and farm income; by reducing the maintenance (both in terms of physical and financial liabilities), dispute over water and by reducing the soil erosion.

The deferred repair and maintenance of the irrigation system, particularly after the onset of drought in 1998, is the main issue due to which the discharge of the karezes close to the daylight points has been reduced by $47 \%$. Further $25 \%$ of the available water is being lost during conveyance. About $186,624 \mathrm{~m}^{3}$ of water leaves the area from December to March because of no use. No public investment made on the minor irrigation scheme is recovered from the farmers, resulting in lack of ownership of the scheme.

The karez system is unique in the world and provides water free of cost to the local community round the clock and throughout the year. It must therefore, be sustained. For sustainable management of the karezes, these should be regularly cleaned and protected from floods. Watershed management and artificial recharge activities should be carried out on the upstream of the mother wells of the karezes. Irrational installation of tubewells particularly within the karez recharging zone must be banned and any violation in this regard should be dealt strictly.

Acknowledgements: The study was conducted under the financial support of the IUCN Pakistan.

\section{REFERENCES}

Abernethy, C.L. 1986. Performance measurement in canal water management: A discussion. ODI-IIMI Irrigation Management Network Paper 86/2d. pp.25.

Ashraf, M. and A. Majeed. 2006. Water requirements of major crop for different agro-climatic zones of Balochistan. IUCN, Water programme, Balochistan Programme Office.

BCS. 2000. Balochistan Conservation Strategy. IUCN Pakistan and Government of Balochistan.

BMIADP. 1987. Balochistan Minor Irrigation and Agricultural Development Project: Accelerated Implementation Programme. Screening Report No. 16, Dilsora Perennial Irrigation Scheme. Halcrow-Ulg Ltd and Engineering Consultants, October, 1987.

GOP. 2001. Ten years perspective development plan 2001-11 and three year development program 2001-2004, Planning Commission, Govt. of Pakistan.

Gorantiwar, S.D. and I.K. Smout. 2006. Model for performance based land and area allocation within irrigation schemes. Irrig. Drain. Syst. 20:345-360.

Huppert, W., M. Svendsen and D.L Vermillion. 2003. Maintenance in irrigation: Multiple actors, multiple contexts, multiple strategies. Irrig. Drain. Syst. 17:5-22.

Kahlown, M.A., M.A. Tahir, H. Rashid and K.P Bhatti 2006. Water Quality Status: Fourth Technical Report 20042005. Pakistan Council of Research in Water Resources, Islamabad, Pakistan.

Kloezen, W.H., C. Garaces-Retrepo and S.H. Johnson III. 1997. Impact assessment of irrigation management transfer in the Alto Rio Lerma irrigation district, Mexico. Research Report 15, IWMI, Colombo, Sri Lanka.

Lam, W.F. 1996. Improving the performance of small-scale irrigation systems: The effects of technological investments and governance structure on irrigation performance in Nepal. World Develop. 24:1301-1315.

McKay, J. and G.B. Keremane. 2006. Farmers 'perceptions on self-created water management rules in a pioneer scheme: The Mula irrigation, India. Irrig. Drain Syst. 20:205-223.

Murray-Rust, D.M., M. Svendsen, M. Burton and D.J. Molden. 2003. Irrigation and Drainage systems maintenance: Needs for research and action. Irrig. Drain. Syst. 17:129-140.

New Civil Engineer. 1996. Keeping Track of Maintenance. Thomas Telford, London.

Nijiman, C.M. 1992. Performance evaluation and control in water delivery decision making process. Irrig. Drain. Syst. 6:85-112.

Ostrom, E., L. Schroeder and S. Wynne. 1993. Institutional Incentives and Sustainable Development. Westview Press, Boulder, CO. 
Pereiera, L.S. 1996. Inter-relationship between irrigation scheduling methods and on farm irrigation methods. In: Irrigation scheduling: from theory to practice. FAO Water Report No. 8, FAO, Rome.

Pinstrup-Anderson, P., R. Pandya-Lorch and M.W. Rosergrant. 1997. The world food situation, recent developments, emerging issues, and long-term prospects.
Food Policy Report, International food Policy Research Institute, Washington, D.C.

Small, L.E. and M. Swendsen. 1990. A framework for assessing irrigation performance. Irrig. Drain. Syst. 4:283-312.

Vermillion, D.L. 1997. Impact of irrigation management transfer: A review of the evidence. Research Report 11. IWMI, Colombo, Sri Lanka. 